\title{
On the Temporalities of Crisis and Puerto Rican Resistance
}

\author{
Pedro Noel Doreste \\ University of Chicago \\ doreste@uchicago.edu \\ http://orcid.org/0000-0002-7952-7811
}

This past summer, under the constraints of Chicago's strict COVID-19 regulations, the Museum of Contemporary Photography organized an exhibition titled Temporal: Puerto Rican Resistance, curated by Dalina Aimée Perdomo Álvarez. Temporal examines various strands of resistance throughout Puerto Rico's 120-year-long history as a United States colony, privileging three major events of the past decade: the enactment of a U.S. federal law (PROMESA), which further undermined local autonomy and deployed a wave of austerity measures to ensure repayment of the island's debt, the manifold failures of U.S. federal aid to Puerto Rico after Hurricane María in 2017, and the popular upswell which resulted in the governor's ouster in summer 2019. The exhibition's title can be understood to be pushing back against the cult of resilience, which charges the people of Puerto Rico, all victims of disasters natural and unnatural to varying degrees, as the party responsible for picking up the pieces. At once alluding to time, to the colloquial word for "storm," and to the popular plena songa style of music of Afro-Caribbean origin often referred to as a "sung newspaper"-the triple-meaning implied by the show's title finds its dispatch in its photographic and multimedia installations, telling us its stories but also telling time.

The main gallery offers us striking disorientation of domestic life in Puerto Rico after Hurricane María, blurring epistemological boundaries between inside and outside, light and dark, leisure and labor. The first wall offers the quotidian renderings of island lives lived in utter darkness as power lagged to be restored to the population after the island-wide collapse of the electrical grid for months on end. These infrastructural inadequacies bleed into the images themselves - all of them lit by a single source of lightshowing its subjects struggling to complete homework in the dark, or 
cooking family dinners by lamplight. In one striking example, Erika P. Rodríguez's Parranda (Figure 1), a group can be seen beating hand drums and singing what the viewer may presume is a plena song. This representation of communal leisure extends beyond the discourses of stoic resilience proposed by the other photographs in the series, ${ }^{1}$ as the faintly illuminated scene captures the insurgent joy of tradition amidst the failures of political and infrastructural modernity. The plena, calling to mind David Joselit's definition of heritage as a mode of reanimating the past that can break with or imagine alternatives to modernity (Joselit 2020: 7), ignites in this image the organizing principle of the exhibition: the intersection of the musical tradition and the radical. The genre's Afro-Caribbean percussion, its supple repetitions, and its call-and-response format encourage the viewer to experience the show's voyages through colonial time as aestheticized, multisensory reportage beyond the mere visual. This motif is further evinced by Mari Robles López's mixed-media piece Me tienen miedo será, in which protest photography is adhered onto the battered pots and pans used as makeshift percussion instruments throughout the recent wave of protests on the island and, in fact, across Latin America. Despite the relative silence of the museum, the rhythms of the plena can be felt in the dents and in the dark.

Elsewhere in the main gallery, daylight reveals the plight of hurricane survivors. Immediately, the viewer can recognize that the images do not

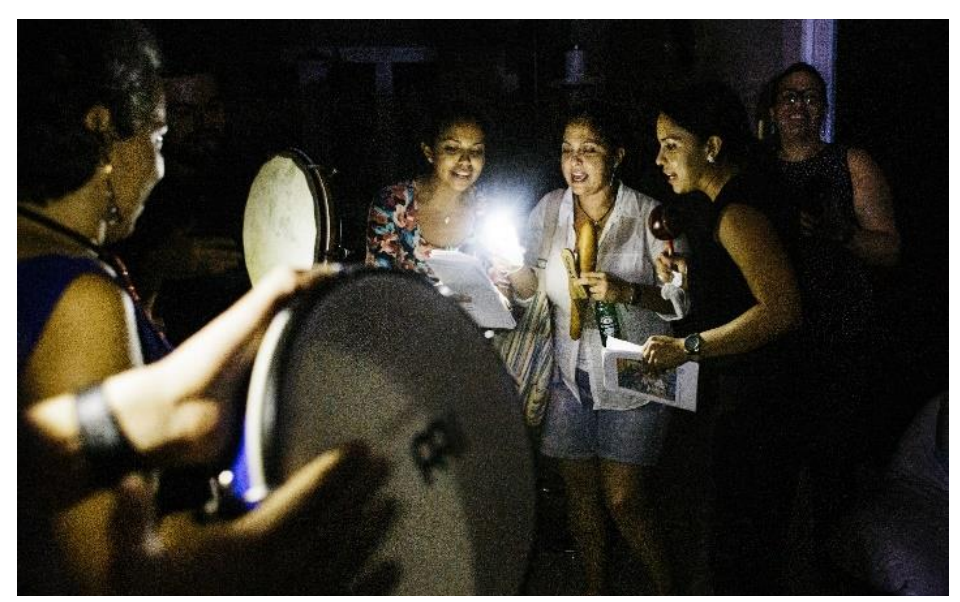

Figure 1: Erika P. Rodríguez, Parranda, 2017. Courtesy of the artist.

${ }^{1}$ Yarimar Bonilla calls this a "cult of resilience" or, "a new ideology in which the state is imagined as incapable of eliminating threats-both political and environmental-or addressing their causes. Instead, communities and individuals must bear the brunt of mitigating rising threats of violence-both slow/structural and spectacular" (Bonilla 2020). 
resemble those in front covers of newspapers or magazines. Instead, these photographs, largely showing outside landscapes and residents running errands amidst the debris, indulge in a type of disaster kitsch, frustrating the expectation of suffering and ruin with candid, if not off-kilter portraits of self-care among the ruins. One photograph may show the colorful façade of a typical rural dwelling-so attractive and well-kept that we may be momentarily tempted to overlook the fact that the rest of the house is missing. Another photograph printed on the blue tarps distributed by the Federal Emergency Management Agency-now synonymous with blightshows a long-abandoned house with graffiti sprayed on its outside bearing a phone number and pleading with FEMA to get in touch (right-hand wall in Figure 2). This island humor is an all-too-familiar coping mechanism, but here it also serves as lucid, playful indictment of the botched federal response to the disaster.

This curatorial touch inscribes each piece with an intimacy typically foreclosed to disaster photography, in that its subjects are allowed to reckon with the aftermath on their own terms and momentarily freed from the rigid dogma of reconstruction. In the deep of the main gallery, artist Edra Soto's foreboding, mock iron installation looms over the space and speaks to an extended chronology of displacement. The large, jet black panel mimics the architectural style of a typical Caribbean front porch. Small viewfinders featuring iPhone photographs taken during and after the hurricane invite us to look into low-resolution scenes of fallen trees, an impossibly purple-hued sky, and television news reports tracking the storm's landfall. These images, taken with the artist's iPhone, show the common trappings of natural disaster, yet GRAFT (Figure 2) makes the viewer aware of their perspective as voyeurs of the island's wreckage from the outside, an intimation of the artist's own position as a Chicago transplant returning to the island. Building on Soto's contemplation of migration and displacement, Kiskeya Salón by Ojos Nebulosos conforms to the spatial logic of the main gallery as a walk-through installation that recreates wholesale the gendered space of a Dominican hair salon and the experience of walking into a local storefront. In a country that has carefully crafted a national identity based of the mythical figure of the white creole, these migrant enclaves in the island are one of the few in which blackness is openly celebrated, here tucked into the smallest room in the museum just as it would into a retail space of a San Juan alley. Both installations, plucked and grafted here from their original contexts, reveal the marginal discourses of Puerto Ricanness that so often exclude the voices in the diaspora or Caribbean migration into the U.S. territory. On the one hand, as 
the largest immigrant group in Puerto Rico, the Dominican community has long been subject to racist and xenophobic attacks despite strong cultural affinities between the two islands. On the other, the Puerto Rican diaspora living in the U.S. have been typically ascribed a qualified Puerto Rican identity, a notion exacerbated by the onset of survivor's guilt or, as Yarimar Bonilla describes, the feeling that they have abandoned ship in search for better lives (Bonilla 2020). Both pieces speak to the negotiated endurance of these communities facing duress from both outside and within. If we are to take seriously the premise of \#PuertoRicoSeLevanta - a popular, posthurricane rallying cry that roughly translates to "Puerto Rico rises" - Soto's and Ojos Nebulosos' installations beg the question of who will be allowed to rise with it.

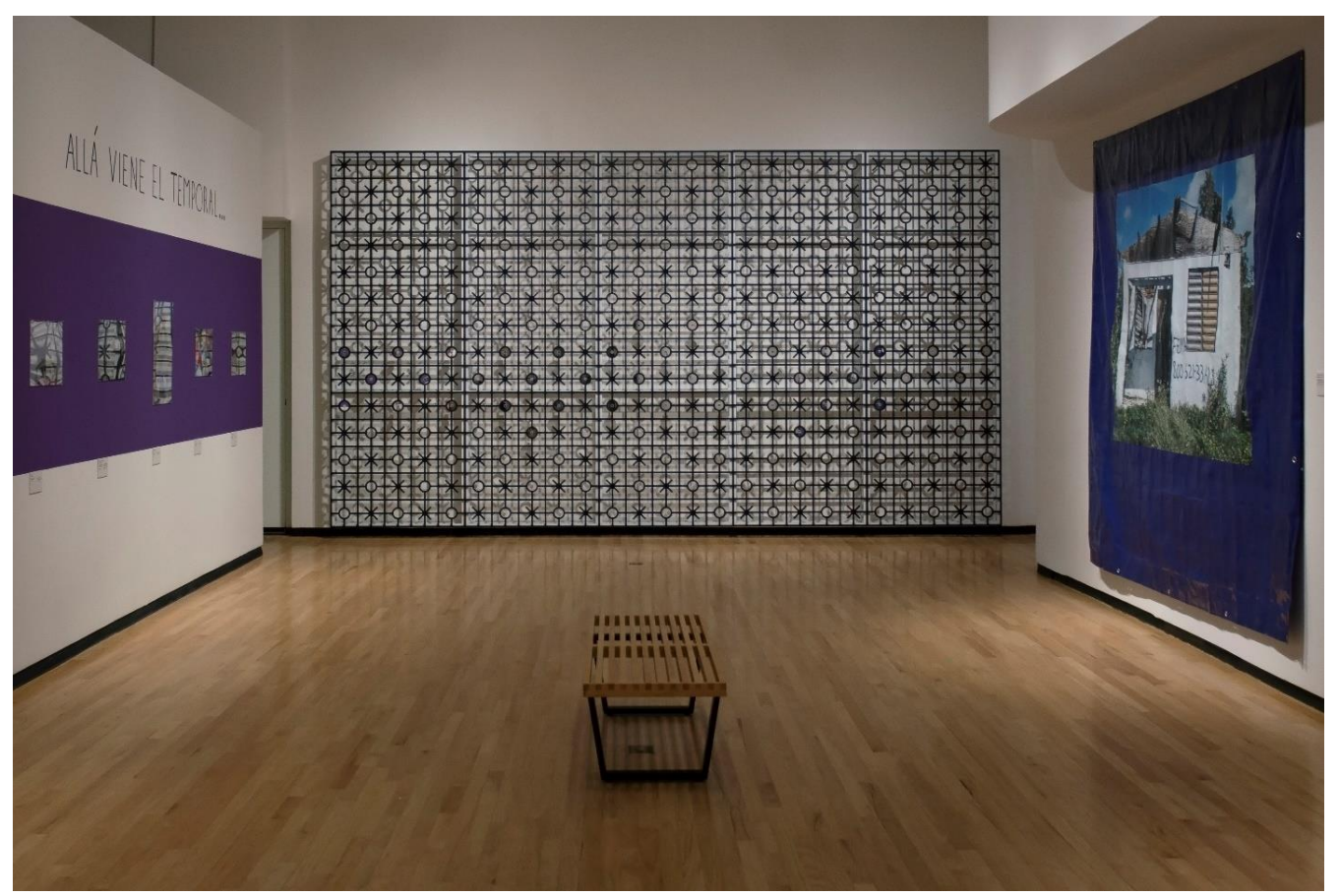

Figure 2: Installation shot, main gallery. Courtesy of the Museum of Contemporary Photography.

The mezzanine gallery displays photographs from Christopher Gregory Rivera's Las Carpetas (Figure 4), a series in which he captures a physical archive of surveillance documents assembled by the Puerto Rican Police in 
collaboration with the FBI from the 1940 s to the 80s..$^{2}$ The carpetas, or the files, were only unsealed in 1992 . The revelation of this massive surveillance apparatus has cultivated a deep distrust between the \citizenry and the state, the latter understood here as both colonial administration and U.S. law enforcement presence on the island. Gregory Rivera's re-photography project, however, also highlights the strategic ruptures generated by this unconstitutional practice within the Puerto Rican independence sector. Each case file is written by hand, each piece of confiscated material taken by force, and photographic evidence of a suspect's participation in antigovernment rallies or protests relied on tips proffered by community informants, as evinced by the varying calligraphy and equivocating descriptions on the back of the surveillance photograph in Figure 3. This exercise in documenting archival residue provides the exhibition a belated historical framework, allowing for the visitor to work their way backwards or detach themselves from the current news cycle. Las carpetas reveals the function of the archive as an organ of state repression not merely to mourn a people's freedom denied, but to insist on the effectiveness of protest as an agent of change, clandestine and popular-or both.
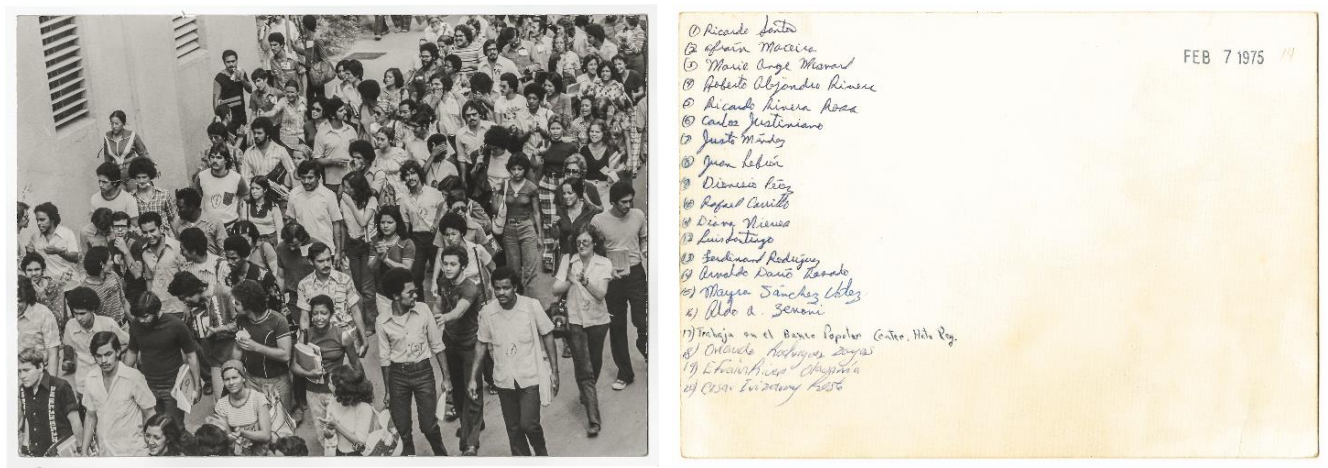

Figure 3. Christopher Gregory-Rivera, Las carpetas series, 2014-2017, courtesy of the artist

The idea of "dead time" is a subject of attention for anyone who studies the history of Puerto Rico under the yoke of colonialism. ${ }^{3}$ Given the

\footnotetext{
${ }^{2}$ As Marisol Lebrón and others have argued, surveillance of perceived subversive groups in Puerto Rico has only become more sophisticated in the digital age, particularly after the passage of PROMESA in 2016 (Lebrón 2007, 159).

${ }^{3}$ The concept of "dead time" or the feeling of being suspended in history are often invoked to describe waits and suffering ranging from the interregnum between sugar harvests to the continued struggle for political sovereignty (Ayala \& Bernabe 2007, 142). This idea is further examined by the exhibition's two video installations, Natalia Lassalle-Morillo's La ruta (three-channel video, 2018) and Rogelio Báez Vega Field Day (sculpture/video installation, 2020), both of which revisit the midcentury developmentalist projects in education and tourism in their present state of dystopian urbanism.
} 
archipelago's popularizing status as "the oldest colony in the world"-a 523-year-old possession of either the Spanish or U.S. empires-it has proven stubbornly seductive to consider grassroots forms of political organizing as dead ends. Eulogies of Puerto Rican dissidence notwithstanding, the final gallery is an attempt to capture the scale and effervescence of contemporary political struggles following the global recession of 2007, whose effects had been felt in the Puerto Rican economy much earlier. Drawing from Rafael Tufiño's epic painting La plena (1952-54, casein on canvas), the "protest room," as it became affectionally termed by the curatorial staff, unravels into a monumentalist depiction of Puerto Rican democracy in action, ranging from student actions against university budget cuts to feminist groups occupying the governor's mansion to demand justice for an increasing wave of misogynist violence to organized revolts calling for the governor's resignation after he was shown mocking the victims of hurricane María in a series of leaked chat messages (Figure 4). Roughly corresponding to Tufiño's original in theme, color, figuration, and placement, the protest room aims to capture the uninterrupted agitations at the intersection of art, culture, and radical politics, both before and after the storm laid these struggles bare on the world stage. Temporal reminds us that to summon "dead time" is not to speak of the dead. It is a testament to political subjectivities and sovereign futures under colonial suspension.

Despite the initial gallery's familiarity to those communities affected by the effects of climate change, whether through photojournalism or social media, Temporal does not wallow in these images of disaster. Unlike many photographic exhibitions and edited collections produced in the wake of Hurricane María, its tone resists the deadening insistence of mourning. It does not assume that María's effect on Puerto Rico was unprecedented or isolated, but instead, the ensuing multimedia arrays trace a lineage between the symbiotic calamities of natural disasters, neoliberalism, and colonialism. 


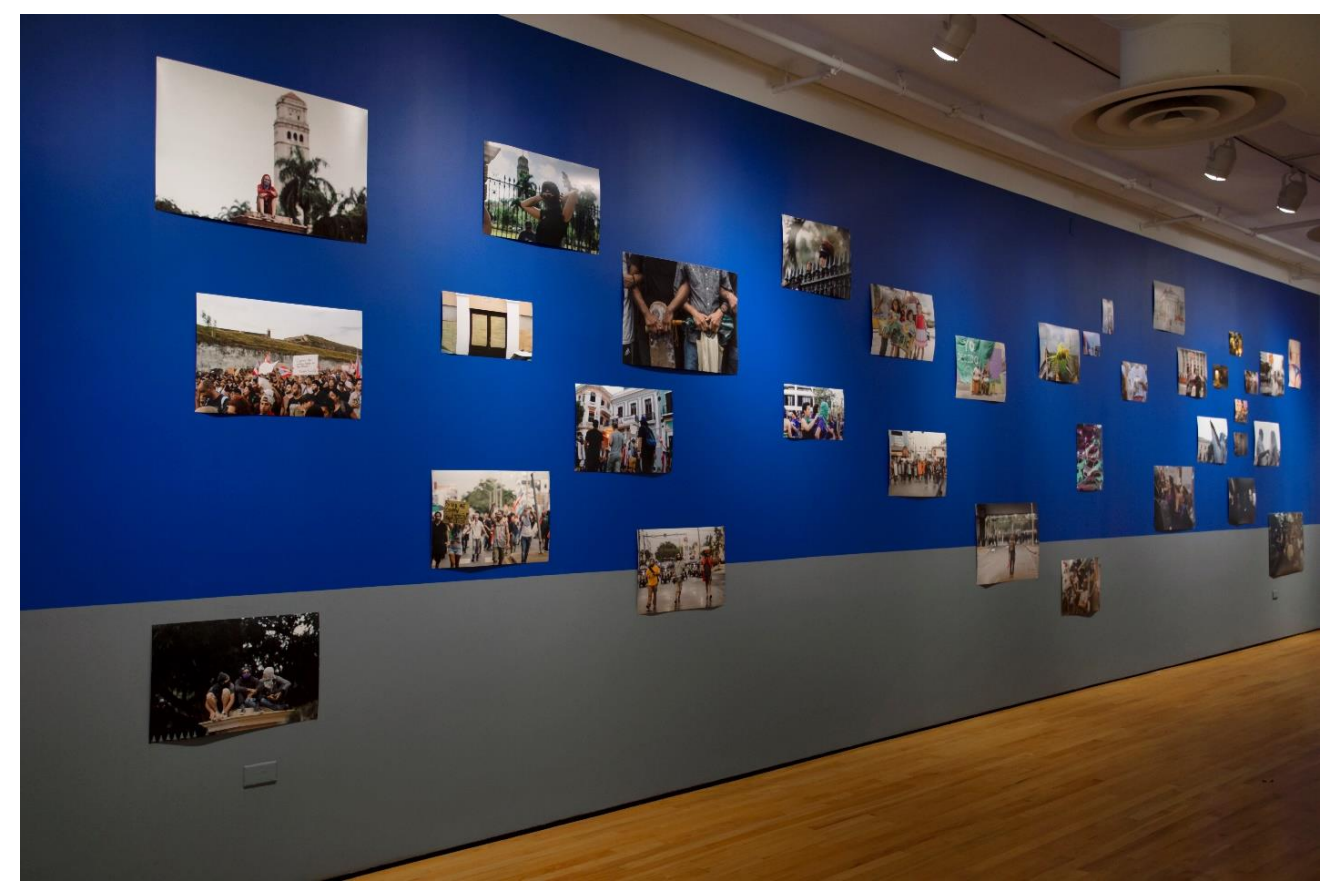

Figure 4: Installation shot, print study room. Courtesy of the Museum of Contemporary Photography.

Laura Briggs once wrote, conspicuously at the time, that Puerto Rico was the most important place in the world, referring to the concentrated effects of globalization in the privatization, deregulation, and other experiments in neoliberal policy-making (Briggs 2022, 195-195). True to the music it takes as inspiration, Temporal is an exercise in keeping momentum, against the colonial condition and the aftershocks of natural disaster, at once elaborating Puerto Rico's relationship with crises and discouraging any reading that would suggest that whatever ails the island is some late-onset malady-or that it may be terminal, for that matter. Temporal rejects the argument that the singular date of September $20^{\text {th }}, 2017$ is the cause of Puerto's current situation and that, despite still fresh wounds, Puerto Rican art should strive to historicize the ways in which contemporary events in the island have merely accelerated long-standing crises, both natural and manufactured, and provide sketches toward resistance.

\section{References}

Ayala, César J and Rafael Bernabe. 2007. Puerto Rico in the American Century: A History since 1898. Chapel Hill: University of North Carolina Press. 
Bonilla, Yarimar. 2020. "The Coloniality of Disaster: Race, Empire, and the Temporal Logics of Emergency in Puerto Rico", Political Geography 78: 1-12.

Briggs, Laura. 2002. Reproducing Empire: Race, Sex, Science, and U.S. Imperialism in Puerto Rico. Berkeley: University of California Press.

Joselit, David. 2020. Heritage and Debt: Art in Globalization. Cambridge: MIT Press.

LeBrón, Marisol. 2017. "Carpeteo Redux: Surveillance and Subversion against the Puerto Rican Student Movement", Radical History Review 128: $147-172$.

anikiExposições e festivais de cinema | Exhibitions and film festivals 